\title{
Coexistence of Hip Torsional Deformities in Patients With Lumbar Disc Herniation; A Case-Control Study
}

\author{
Lomber Disk Hastalığında Kalça Torsiyonel Deformiteleri
}

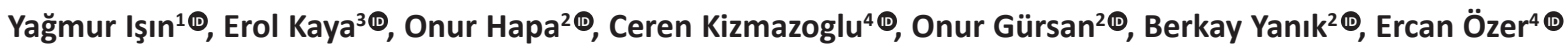 \\ ${ }^{1}$ Department of Orthopedics and Traumatology, Ozel Saglik Hospital, Izmir, Turkey \\ ${ }^{2}$ Department of Orthopedics and Traumatology, Dokuz Eylul University, Izmir, Turkey \\ ${ }^{3}$ Department of Orthopedics and Traumatology, Merzifon Kara Mustafa Pasa State Hospital, Amasya, Turkey \\ ${ }^{4}$ Department of Neurosurgery, Dokuz Eylul University, Izmir, Turkey
}

Geliş / Received: 10.03.2021 Kabul / Accepted: 26.06.2021 Online Yayın / Published Online: 10.08.2021

Cite as: Işın Y, Kaya E, Hapa O, Kizmazoglu C, Gürsan O, Yanık B, Özer E. Coexistence of hip torsional deformities in patients with lumbar disc herniation; a casecontrol study. Turk J Hip Surg 2021;1(2):51-5.

\section{ABSTRACT}

Objective: Coexistence of lumbar spine disorder with hip diseases is defined as Hip-Spine syndrome, there might be a relation between torsional deformities of the hip and lumbar disc disease. Purpose of the present study was to find whether hip torsional parameters (femur, acetabular anteversion) and clinical findings (hip range of motion, hip score) differ in patients with lumbar disc disease.

Method: Patients with lomber disc herniation ( $n: 20)$ and control subjects ( $n: 20)$ without any lumbar spine or hip disease were enrolled in the study. Femoral anteversion (FeAv), acetabular anteversion (AA), center of edge angle (CE), degree of hip flexion, extension, Harris Hip scores (HHS) were evaluated bilaterally. Results: HHS score, degree of extension plus flexion was lower at diseased side when it is compared to the control subjects $(p<0.001)$. Unilaterally affected patients had lower $A A$ than control subjects ( $A A: 13 \pm 40$ vs $16 \pm 20 \mathrm{p:0.01)}$.

Conclusion: As there is a link between hip and spine disorders, present study aims to find whether there is a causal relation between hip torsional deviations and lumbar disc disease. Partially supporting the hypothesis, diseased side had lower degrees of acetabular anteversion compared to control subjects at unilaterally affected patients. Mechanical and /or hip torsional parameters especially the acetabular retroversion may have an etiopathogenetic role in unilateral lumbar disc disease.

Keywords: lumbar disc disease, femoral anteversion, acetabular anteversion

öz

Amaç: Kalça hastalıkları ile lomber omurga bozukluğunun birlikteliği Kalça-Omurga sendromu olarak adlandırlır. Lomber disk hastalığı ile kalça torsiyonel deformiteleri arasında bir ilişki olabilir. Bu çalışmanın amacı, lomber disk hastalığı olan hastalarda kalça torsiyonel parametrelerilfemur, asetabular anteversiyon) ile klinik bulguların (kalça hareket açıklığı, kalça skoru) farklıık gösterip göstermediğini belirlemektir.

Yöntem: Çalışmaya lomber disk herniasyonu olan 20 hasta ile herhangi bir kalça ve omurga rahatsızlığı bulunmayan 20 hastalık kontrol grubu dahil edildi. Femoral anteversiyon (FeAv), asetabular anteversiyon (AA), merkez kenar açısı (CE), kalça fleksiyon ve ekstansiyon dereceleri, Harris Kalça skorları (HHS) bilateral olarak değerlendirildi.

Bulgular: Etkilenen tarafta HHS skoru ve kalça fleksiyon-ekstansiyon dereceleri kontrol grubuna göre daha düşük bulundu(p<0.001). Tek taraflı etkilenen grupta kontrol grubuna göre $A A$ değerleri daha düşük bulundu (AA: $13 \pm 40^{\prime} a$ karşı $16 \pm 20$ p: 0.01).

Sonuç: Kalça ve omurga bozuklukları arasında bir bağlantı olduğundan, bu çalışma kalça torsiyon bozuklukları ile lomber disk hastalığı arasında nedensel bir ilişki olup olmadığııı değerlendirmeyi amaçlamaktadır. Hipotezi kısmen destekleyen, hastalıklı taraf, tek taraflı olarak etkilenen hastalarda kontrol grubuna kıyasla daha düşük derecelerde asetabular anteversiyona sahip olmasıdır. Mekanik ve/veya kalça torsiyonel parametreler, özellikle asetabular retroversiyon, tek taraflı lomber disk hastalığında etiyopatogenetik bir role sahip olabilir.

Anahtar kelimeler: lomber disk hastalı̆ı, Femoral anteversiyon, asetabular anteversiyon

$\begin{aligned} & \text { Sorumlu Yazar / Corresponding Author: } \\ & \text { Yağmur Işın } \\ & \text { yagmurisin2013@gmail.com }\end{aligned}$
$\begin{aligned} & \text { Y. Işın 0000-0002-6047-8597 } \\ & \text { E. Kaya 0000-0002-1774-0537 }\end{aligned}$ $\begin{aligned} & \text { O. Hapa } \\ & \text { C. Kizmazoglu }\end{aligned}$




\section{INTRODUCTION}

The coexistence of lumbar spine disorder with hip diseases is defined as Hip-Spine syndrome and was first described in $1983^{(1)}$. Various hip pathologies like flexion deformities, osteoarthritis, and limited hip range of motion (ROM), possibly femoral retroversion, have been related to lumbar pathologies ${ }^{(1-6)}$. There are reports on the disappearance of lower back pain when hip conditions are treated with hip arthroscopy or arthroplasty ${ }^{(2,3)}$. Besides, in a recent biomechanical study, it was shown that the limitation of the terminal hip extension due to ischio-femoral impingement led to an increase of lumbar facet (L3-4 and L4-5) joint load compared to normal native hips (7).

Additionally, torsional deformities and/ or limited range of motion of the hip have been reported to be linked to hip osteoarthritis. Increased femoral anteversion and /or acetabular retroversion or decreased acetabular anteversion predisposes to hip osteoarthritis ${ }^{(8-13)}$.

The purpose of the present study was to examine the relationship between hip torsional parameters (femur, acetabular anteversion), clinical findings (hip range of motion, Harris hip score), and lumbar disc disease. The hypothesis was that patients with lumbar disc herniation would have decreased femoral and/or acetabular version and ROM compared to control subjects without hip or spine disease.

\section{Patients and methods}

Patients who were recommended to be operated by the Department of Neurosurgery due to lumbar disc pathology, who were evaluated in the Orthopedics and Traumatology outpatient clinic, whose examination forms were filled in completely, and patients who had pelvis $\mathrm{CT}$ and $\mathrm{x}$-rays in the archives of the department of radiology were determined. Patients whose CT images were not taken in the ideal position for measurement, patients with missing range of motion and scoring, those with osteoarthritis findings on radiological evaluation, and cases with neurocognitive disorders such as Alzheimer's and dementia were excluded from the study. Examination forms and radiological images of all patients were analyzed retrospectively. Patients with lumbar disc herniation without any hip-related symptoms and osteoarthritis findings at their pelvic $x$-rays, those who were elected for surgery at our neurosurgery department, comprised the study group (Group P). The control group (Group C) was determined based on the computed tomography (CT) analysis of hip joints that had already been performed on patients who were referred to our radiology department because of abdominopelvic diseases and who had healthy hip joints in their scanograms without any symptoms related to lumbar vertebrae or hip joint. The local ethics committee approved this study (2021/20-39). Written and informed consent was obtained from both the patients and the control subjects.

Twenty patients (Group P), and 20 control subjects (Group C) were included. Demographic data is present in Table I.

Table I. Demographic data of the groups.

\begin{tabular}{|c|c|c|}
\hline & Patients (N:20) & Control (N:20) \\
\hline Age & 44(23-69) & 43(18-58) \\
\hline Sex & 7F,13M & $9 F, 11 M$ \\
\hline $\begin{array}{c}\text { Side and } \\
\text { level }\end{array}$ & $\begin{array}{c}\text { L4-5, left; 4, L4-5, right;6, L5-S1, } \\
\text { left; 4, } \\
\text { L5-S1, right;3, L4-5, bilat: 3. }\end{array}$ \\
\hline
\end{tabular}

*F:Female, M:Male

The CT examinations were performed in a supine position with femurs in neutral rotation and the hips and knees in extension. Scanograms were obtained from between the anterior superior iliac spine and the level distal to the knee joint in the frontal plane (14).

Femoral anteversion (FeAv), acetabular anteversion (AA), the center of edge angle (CE), degree of hip flexion, extension, Harris Hip scores (HHS) were evaluated bilaterally at both groups $(9-13,15)$.

The FeAv was calculated as the angle between the projected head-neck line and the line that intersects the anterior and posterior condylar tangents. The tomographic section with the most prominent femoral head diameter was projected on the other section with the largest, best femur neck vision ${ }^{(14)}$. The centers of the femur head and femur neck were identified. 
The projected head-neck line was determined by connecting these two centers.

While measuring acetabular anteversion, obliquity caused by improper positioning of the patient in the CT scanner was controlled by drawing a baseline intersecting the ilium's most posterior edges. Acetabular anteversion describes a line's angulation through the anterior lip of the acetabulum and the lip of the posterior acetabulum with the sagittal plane $^{(16)}$ (Figure 1 and Figure 2).

\section{Statistics}

The SPSS for Windows version 15.0 (SPSS Inc., Chicago, IL, USA) was used to analyze the data. The chi-square test was used to compare the groups for the distribution of female and male subjects. MannWhitney $U$ test was used to investigate sex, intergroup difference between variables tested. Wilcoxon signed-rank test was used to compare the parameters of the herniated side to contralateral asymptomatic side.

\section{RESULTS}

There was no difference between groups regarding age and sex $(p>0.05)$. Data are presented in Table II (bilateral sides+unilateral=herniated side, control: mean value of both sides). HHS score, degree of an extension, plus flexion was lower at diseased side compared to control subjects $(p<0.001)$.

When only unilaterally affected patients were included, AA was also lower than control subjects (AA: $13 \pm 4(12)^{0}$, degrees; $\left.\mathrm{p}: 0.01\right)$. At unilaterally affected patients, the diseased side had lower degrees of flexion and extension, HHS points compared to the contralateral asymptomatic side $(p<0.001)$. Furthermore, there was a nearly statistically significant trend of lower AA at the symptomatic side compared to the contralateral side $(p: 0.07)$.

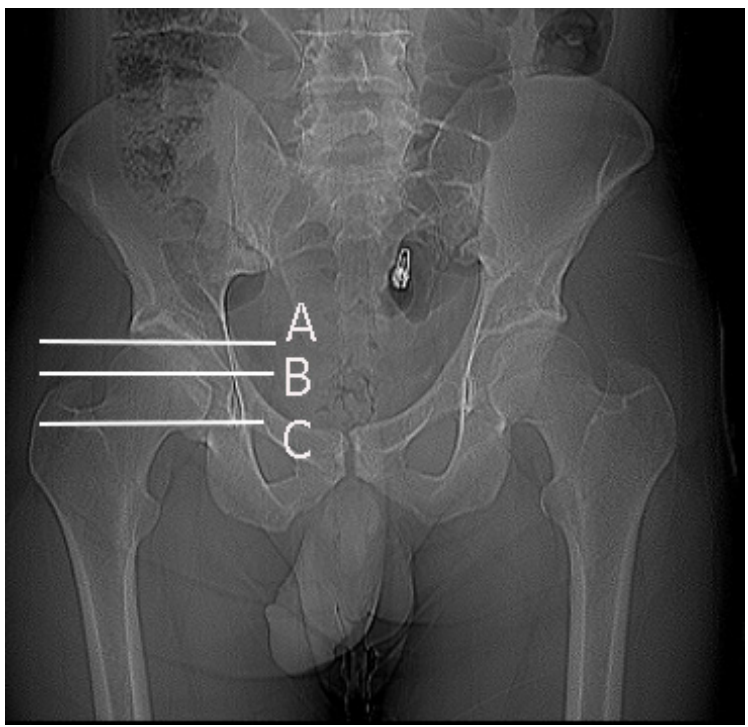

Figure 1. Coronal image showing the acetabulum divided by three lines

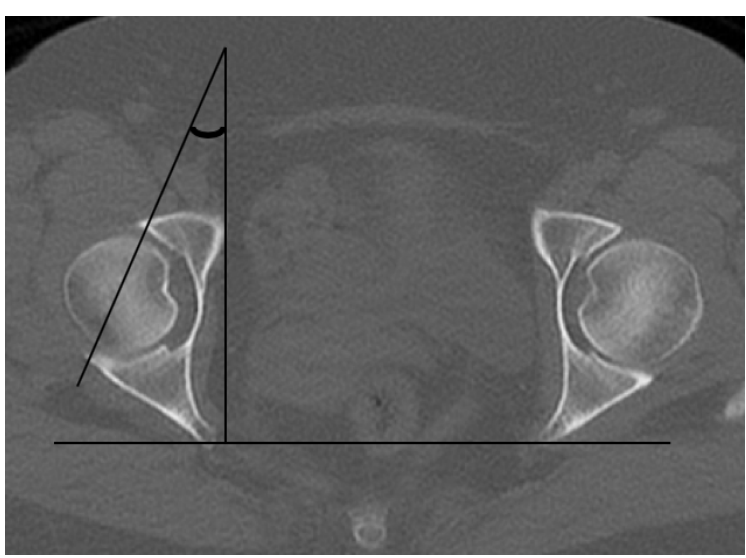

Figure 2. An axial CT image showing how acetabular anteversion is measured

\section{DISCUSSION}

Since there is a link between hip and spine disorders, the present study aimed to find a causal relationship between hip torsional deviations and lumbar disc disease. Partially supporting the hypothesis, the diseased side had lower acetabular anteversion degrees compared to control subjects in unilaterally affected patients.

Table II. Data for the groups.

\begin{tabular}{|c|c|c|c|c|c|c|}
\hline Groups & FeAv & AA $^{(0)}$ & CE$^{(0)}$ & Flex & Exten $^{(0)}$ & HHS(points) \\
\hline Herniated side (n:23) & $11 \pm 7(9)$ & $14 \pm 5(13)$ & $43 \pm 5(43)$ & $94 \pm 6(95)$ & $4 \pm 1(4)$ & $62 \pm 12(64)$ \\
\hline Control group (mean) (n:20) & $13 \pm 6(14)$ & $16 \pm 2(16)$ & $40 \pm 5(40)$ & $102 \pm 5(101)$ & $8 \pm 1(8)$ & $92 \pm 2(91)$ \\
\hline
\end{tabular}

*FeAv:Femoral anteversion, AA:Acetabular anteversion, CE:Center of edge angle, Flex:Flexion, Exten:Extension HHS: Harris Hip Score 
Both femoral anteversion, and acetabular anteversion abnormalities have been described in the pathogenesis of hip osteoarthritis ${ }^{(8-13,17)}$, and hip osteoarthritis is being linked to lumbar spine disease. However, none of the studies in the literature directly searched causal relationships of these parameters in lumbar disc disease. The present study found no difference when bilateral cases were included, which may point to the etiopathogenetic role of mechanical and /or hip torsional parameters in unilateral disease.

According to a recently reported review, patients with low back pain frequently had limited hip range of motion, especially during the flexion of the hip and back pain of the patients was relieved when hip osteoarthritis was treated with arthroplasty (2). However, the reviewers did not find any study pointing out the beneficial effect of the improvement in the internal rotation of the hip after hip arthroscopy performed for femoro-acetabular impingement on lumbopelvic stress. In contrast with the findings of this study, patients with advanced hip osteoarthritis receiving hip arthroplasty with nonspecific lumbar spine disease were reported ${ }^{(2,3,38)}$.

We also found decreased hip flexion and extension in patient groups similarly reported in the literature. Recently Chadayammuri et al. reported decreased degree of hip flexion (mean 104 ${ }^{\circ}$ ) with acetabular retroversion with no effect on femoral torsion ${ }^{(8)}$. In an anatomic study of ischio-femoral impingement model with concomitant decrease of terminal hip extension, Gomes-Hoyos et al. reported an increase of the L3-4 and L4-5 lumbar facet joint load ${ }^{(7)}$.

There are several limitations of this study . First, we excluded hip osteoarthritis with the questioning of symptoms and from pelvic radiographs and did not stage precisely the status of the hip according to the Tönnis staging, which in turn, early stages of Tönnis grading might have influenced the results (13). Secondly, we did not measure the degree of hip rotation and abduction/adduction, since we did not specifically look for the presence of femoroacetabular impingement, but rather measured the main movement arc of the hip 'flexion/extension', which is reported to be linked to spine disorders ${ }^{(2)}$. Although patients were under pain medication during the study, loss of hip extension, and flexion might have been overestimated by the patient group due to possible muscular spasm secondary to back or leg pain. Lastly, we did not evaluate the effect of grade or the lumbar disc herniation level, which possibly will be the subject of future studies.

Ethics Committee Approval: The local ethics committee approved this study (2021/20-39)

Conflict of Interest: None

Funding: None

Informed Consent: Written and informed consent was obtained from both the patients and the control subjects.

\section{REFERENCES}

1. Offierski CM, MacNab I. Hip-spine syndrome. Spine (Phila Pa 1976). 1983;8(3):316-21. https://doi.org/10.1097/00007632-198304000-00014

2. Reikerås $\mathrm{O}, \mathrm{H} \varnothing$ iseth $\mathrm{A}$. Femoral neck angles in osteoarthritis of the hip. Acta Orthop Scand. 1982;53(5):781-4. https://doi.org/10.3109/17453678208992292

3. Ben-Galim P, Ben-Galim T, Rand N, Haim A, Hipp J, Dekel S, et al. Hip-Spine Syndrome: The Effect of Total Hip Replacement Surgery on Low Back Pain in Severe Osteoarthritis of the Hip. Spine (Phila Pa 1976) [Internet]. 2007;32(19). Available from: https://journals.Iww.com/spinejournal/Fulltext/2007/09010/ Hip Spine Syndrome The Effect of Total Hip.11.aspx https://doi.org/10.1097/BRS.0b013e318145a3c5

4. Fogel GR, Esses SI. Hip spine syndrome: management of coexisting radiculopathy and arthritis of the lower extremity. Spine J. 2003;3(3):238-41.

https://doi.org/10.1016/S1529-9430(02)00453-9

5. Lejkowski PM, Poulsen E. Elimination of intermittent chronic low back pain in a recreational golfer following improvement of hip range of motion impairments. J Bodyw Mov Ther. 2013;17(4):448-52. https://doi.org/10.1016/j.jbmt.2013.01.004

6. Donovan J, Cassidy JD, Cancelliere C, Poulsen E, Stochkendahl MJ, Kilsgaard J, et al. Beyond the spine: a new clinical research priority. J Can Chiropr Assoc [Internet]. 2015 Mar;59(1):6-12. Available from: https://pubmed.ncbi.nlm. nih.gov/25729080

7. Gómez-Hoyos J, Khoury A, Schröder R, Johnson E, Palmer IJ, Martin HD. The hip-spine effect: a biomechanical study of ischiofemoral impingement effect on lumbar facet joints. Arthrosc J Arthrosc Relat Surg. 2017;33(1):101-7. https://doi.org/10.1016/j.arthro.2016.06.029

8. Chadayammuri V, Garabekyan T, Bedi A, Pascual-Garrido C, Rhodes J, O'Hara J, et al. Passive Hip Range of Motion Predicts Femoral Torsion and Acetabular Version. JBJS [Internet]. 2016;98(2). Available from: https://journals.Iww.com/ jbjsjournal/Fulltext/2016/01200/Passive_Hip_Range_of_ Motion Predicts Femoral.6.aspx https://doi.org/10.2106/JBJS.0.00334

9. Halpern AA, Tanner J, Rinsky L. Does persistent fetal femoral anteversion contribute to osteoarthritis?: a preliminary report. Clin Orthop Relat Res. 1979;(145):213-6. https://doi.org/10.1097/00003086-197911000-00033 
10. Giori NJ, Trousdale RT. Acetabular retroversion is associated with osteoarthritis of the hip. Clin Orthop Relat Res. 2003;417:263-9.

11. Menke W, Schmitz B, Schild H, Köper C. Transverse skeletal axes of the lower extremity in coxarthrosis. Z Orthop Ihre Grenzgeb. 1991;129(3):255-9. https://doi.org/10.1055/s-2008-1040192

12. Terjesen T, Benum $P$, Anda S, Svenningsen S. Increased femoral anteversion and osteoarthritis of the hip joint. Acta Orthop Scand. 1982;53(4):571-5. https://doi.org/10.3109/17453678208992260

13. Tönnis D, Heinecke A. Current concepts review-acetabular and femoral anteversion: relationship with osteoarthritis of the hip. Jbjs. 1999;81(12):1747-70.

https://doi.org/10.2106/00004623-199912000-00014

14. Hapa O, Yüksel HY, Muratlı HH, Akşahin E, Gülçek S, Çelebi L, et al. Axial plane coverage and torsion measurements in primary osteoarthritis of the hip with good frontal plane coverage and spherical femoral head. Arch Orthop Trauma Surg [Internet]. 2010;130(10):1305-10. Available from: https://doi.org/10.1007/s00402-010-1086-3
15. Monazzam S, Bomar JD, Dwek JR, Hosalkar HS, Pennock AT. Development and prevalence of femoroacetabular impingement-associated morphology in a paediatric and adolescent population: a CT study of 225 patients. Bone Joint J. 2013;95(5):598-604. https://doi.org/10.1302/0301-620X.95B5.30118

16. Günal T, Muratli HH, Hapa O, Çelebi L, Gülçek S, Biçimoglu A. Residual axial plane deformities after hip reconstruction for developmental dysplasia of the hip after walking age. J Pediatr Orthop B [Internet]. 2007;16(2). Available from: https://journals.Iww.com/jpo-b/Fulltext/2007/03000/ Residual_axial_plane_deformities_after_hip.2.aspx https://doi.org/10.1097/01.bpb.0000236231.19151.8d

17. Ezoe M, Naito M, Inoue T. The prevalence of acetabular retroversion among various disorders of the hip. JBJS. 2006;88(2):372-9. https://doi.org/10.2106/00004623-200602000-00017

18. Hsieh P-H, Chang Y, Chen DW, Lee MS, Shih H-N, Ueng SWN. Pain distribution and response to total hip arthroplasty: a prospective observational study in 113 patients with endstage hip disease. J Orthop Sci. 2012;17(3):213-8. https://doi.org/10.1007/s00776-012-0204-1 